\title{
SUSTAINABLE DEVELOPMENT OF RURAL AREAS - CASE STUDIES VOJVODINA - SERBIA
}

Dejana Forcan", University Singidunum in Belgrade, Serbia

Mladen Ivić, University of Business Engineering and Management, Banja Luka Dragan Đuranović, University in Novi Sad, Serbia

Veljko Vuković, University of Business Engineering and Management, Banja Luka

\begin{abstract}
One of the most important strategic aims of Serbian economic development is supporting of the villages sustainable development through rural economy diversification where rural tourism development has an important place. In spite of this model of tourism importance recognition as a possible way of rural areas development, Serbia is in an opening phase of. Although there are several positive examples, it is significant that recent projects haven't been established according to national and European development programs, but according to private initiatives of individuals and groups. Rural tourism is an important component of integrated and sustainable development and revitalization of villages, as well an an important factor in encouraging the development of local agricultural and non-farmer activities in rural areas and villages, and also a special incentive to employment. This work highlights the importance of rural tourism in the function of the revitalization of the village, focusing on the challenges of the environment and the possible directions of development in the context of creating a recognizable tourist product and brand of rural tourism in Vojvodina.
\end{abstract}

Keywords: marketing, revitalization, development, EU funds, strategic management

JEL Classification: Z3

\section{ODRŽIVI RAZVOJ RURALNIH PODRUČJA - STUDIJE SLUČAJEVA VOJVODINA-SRBIJA}

Sažetak: Jedan od najvažnijih strateških ciljeva srpskog ekonomskog razvoja je podrška održivog ruralnog razvoja preko ruralne ekonomske diversifikacije, gde razvoj seoskog turizma ima značajno mesto. Uprkos ovom modelu prepoznavanja značaja turizma kao mogućeg načina za razvoj ruralnih sredina, Srbija je u početnoj fazi. Pored trenutno nekoliko pozitivnih primera, značajno je da skorašnji projekti nisu bili uspostavljeni na

*dejanaforcan@hotmail.com 
osnovu nacionalnog $i$ evropskog razvojnog programa, nego na osnovu privatne incijative pojedinaca $i$ grupa. Seoski turizam je važna komponenta integrisanog $i$ održivog razvoja i revitalizacije sela, a takođe $i$ važan faktor u ohrabrivanju razvoja lokalnih poljoprivrednih i ne-poljoprivrednih delatnosti u ruralnim sredinama i selima, a takođe i poseban podsticaj za zapošljavanje. Ovaj rad ističe važnost seoskog turizma u funkciji revitalizacije sela, fokusirajuci se na izazove životne sredine i mogućeg pravca razvoja u kontekstu stvaranja prepoznatljivog turističkog proizvoda $i$ brenda seoskog turizma u Vojvodini.

Ključne reči: marketing, revitalizacija, EU fondovi, strategijski menadžment

\section{INTRODUCTION}

Sustainable and Rural Development, in world terms, first promoted in the document Agenda 21, the global plan of action for achieving sustainable development in the XXI-st century, brought to the United Nations Conference on Environment and Development (UN Conference on Environment and Development), held in Rio de Janeiro in June in 1992 (Lopandić, 2004).

In 2005 European Commission has launched a new touristic strategy "According to stronger partnership for European tourism". Revived policy of sustainable tourism was suggested through Lisbon strategy in February 2005 and three key directives of future development were emphasised: 1) challenge of growth and employment, 2) challenge within tourism and 3) dialogue and partnership between interest holders (stake holders) in tourism (Lopandić, 2007).

EU tourism development support is noticeable through numerous miscellaneous programs established on partnership and cooperation principals of state members (and potential members) where touristic economy have a common aim to harmonize touristic sector of European Union through better education and training of personnel, recruitment increasing, faster development of regions, better information and natural and cultural heritage preservation and enhancement. Marketing experts in 21 century are increasingly aware of the need to possess a more complete and more connected approach that goes beyond the traditional application of marketing concepts (Mihić, Andrejević, \& Mihajlović, 2012a).

\section{TOURISM AS AN INSTRUMENT OF EU POLICY FOR RURAL DEVELOPMENT}

Rural development concept of European Union was changing and developing constantly during the time: from land consolidation and infrastructure development, through national programs for agriculture workers support, to EU SCHOOL OF BUSINESS, 2/2016, 1 - 13 

SERBIA

policy making for regional and rural section development. Different programs of support for rural and regional development were evolved (Mihić, Golušin, \& Mihajlović, 2011). The tendency of seventies was villages renewing, but in eighties the programs of nature and eco-system preservation and recreation areas construction were actual. The nineties were marked by structural EU funds for rural development, when a special accent was put on rural development and regional management (Mihić, Drobac, \& Mihajlović, 2010).

New ways of rural areas revitalization searching born a new concept, at first integral rural development and multifunctional agriculture activity, and later similar concepts which have made diversification of economy activities in villages (including tourism), rural landscape preservation, environment protection and advancement and reaffirmation of traditional cultural villages' values (Muhi, 2011).

Rural areas occupy $90 \%$ of European Union territory and $60 \%$ of its inhabitants live there. Agriculture and forestry use the biggest part of land and have the key role in natural resources management in rural areas (Tomić et al., 2004). The synergies of agriculture and tourism provide socio economic development of rural areas and it is a platform of economic diversification in rural communities and pursuant to that rural development policy becomes one of the biggest priorities of European Union (Mihić, Andrejević, \& Mihajlović, 2012b). Recent experience of huge numbers of countries shows that the main support ofrural economy can't be only agriculture, but also a wide spectrum of activities founded just on non-activated potentials of rural areas as touristic potential is. So, the most importance is given to an additional economic activity, from which is expected the most, tourism in rural areas (Muhi, 2011).

Having on mind multiple positive effects of touristic activities (especially economic), European Union undertakes numerous simulative measures which common purpose is development impetus for all relevant types of tourism, touristic turnover and consumption in the rural regions. These measures have a wide spectrum of appliance and effect and especially are directed to tourism development impetus, natural and other resources valorisation, permanent increasing of touristic products quality, export of goods and services stimulation through touristic activities, establishing of tourism management appropriate model, better organization, more efficient preservation of natural environment etc. (Muhi, 2013).

Tourism development is a heterogeneous and dynamic economic, social, areal and political feature which affects rural areas positively and negatively, what have to be put into consideration during preparation and implementation of program's activities. The positive effects are before all possibility of new working places opening and additional income realization which remains within 
local and regional outlines, higher degree of environment preservation through enhanced interest for its constitution and organization, revitalization of cultural and architectural heritage, permanent connection establishing between local communities and domestic or international markets. The trend in our immediate environment imposes the need for Serbia to join the intensified these trends (Mihić et al., 2013). Negative effects comprise conflicts between different activities in a rural environment, various ecological problems induced by enhanced ballast and usage of the area, local settlement living cost increasing, rural areas commercialization etc. (Muhi, 2010).

\section{ROLE OF TOURISM IN THE REVITALIZATION OF VILAGES AND RURAL AREAS}

Rural tourism is both old and new phenomena. Interest in recreation in the countryside of Europe began to rise already in the nineteenth century, in response to the growing pressures of urbanization and industrialization (Muhi, 2012). The United Nations World Tourism Organization (UNWTO) concludes, based on detailed analysis, that mass tourism and recreational habits of citizens are less and less oriented on "tourism under sun". Also, the interest towards untouched nature is growing. Natural resources and cultural heritages are preferred more and more in the rural areas, and other environments besides urban ones.

Rural tourism looks like an appropriate tool for revitalization of abandoned rural areas and providing their sustainability in future through preservation of work places or making new ones, increases the diversity of professions, preserves landscape and nature supports preservation of village handicrafts as tourist attraction. (Muhi, 2012).

The main objective of rural tourism is that, based on the tourism demand, provide additional income to rural population and thus improve their living standards and reduce emigration. Tourism policies should also be applied to help to raise the standard of living of population in the regions visited andmeet their needs. Local people should be linked with tourism activities and participate in an equitable distribution of economic, social and cultural benefits they bring, especially in direct and indirect jobs resulting from them. (Muhi, 2012). Rural tourism is a real asset for revitalization of many small and large rural spatial entities, if not quite abandoned, then very sleepy. The development of tourism in these areas can stop the emigration of young people, because the development of tourism today meanscreating basic conditions for a general, much higher level of village comfort. In such circumstances, young people can find not only economic but also socio-cultural motivations to continue living in 

SERBIA

family homs, in an environment where the general quality of life is really approaching a level that is nowdays considered necessary.

Serbia is a land of rural character and is one of the most agrarian countries in Europe. Rural development, as one of the areas of regional policy, is a key instrument for restricting the agricultural sector and should be tasked to steer the strategic use of the potential of villages attractive to tourists (Plavša, 2007). Given the important economic and other functions of tourism, as well as various and high-value potentials, the spatial plan of Republic of Serbia and its economic policy gives the possibility and proper importance for development of this activity. In addition, the Tourism Development Strategy in Serbia was established selective approach, where rural tourism is treated as a priority under those types of tourism related to the special interests.

\section{RESEARCH METHOD AND RESULTS}

Modern touristic tendencies in many countries of European Union, in many strategies of region and rural areas adjoined village tourism which helps in inhabitants detaining in the place, new working places creation and have contribution in socio economic advancement of backward areas. In the last twenty years, Serbia as a touristic destination has been almost out of international competition, which could be approved by nowadays unassuming results of touristic industry. Touristic resources of Serbia aren't valorised enough (participation in BDP is under 2\% and only over 3\% in employment). Main limitation for tourism development was in political and socio-economic contest of the total country development. Sustainable tourism and its integration with complementary economy activities are not established enough.

The main aim of this paper research is to identify if touristic subjects at rural tourism field in Vojvodina are informed enough about the significance and possibilities of cooperation with institutions and European Union funds; if there is an adequate way of informing about touristic projects investment from European Union funds and if they enough recognize chances and possibilities of cross border and regional cooperation in touristic projects.

The research started with the presupposition that without support system of European Union cognition for tourism development stimulation, without education and without knowledge providing about possibilities of scientific, competent and economic cooperation with European Union institutions and funds, without cross board and regional cooperation of touristic subjects, there is not possible adequate tourism development in Vojvodina.

Having in mind all above mentioned, the research comprises the following: 
- Data collecting from primary sources has been done as a part of the study about tourism development in rural areas and conducted as a poll (variables definition referring to rural tourism field which would be overlooked, indicators determination which at the best possible way represents given variables, representative sample definition for data collecting including all stake holders from rural tourism field.);

- The research is realized at the base of secondary sources, i.e. available data;

- After data collecting completion they were processed into data base and prepared for statistic analyse. Statistics methods which were used are adequate for the features of overlooked indicators and sample characteristics (indicators of descriptive analyse, adequate statistics tests, as well as methods of multi-variation statistic analyse).

Samples of poll taking were stake holders (touristic subjects) who were engaged into village and/or ecological tourism in Vojvodina area. By statistic groups analysing, there was attempt of sample taking of 500 pulleys that were statistically analysed and relevant conclusions were fetched for the whole group.

Poll taking is distributed by e-mail or by direct interview of polled. Touristic subjects were contacted via touristic organizations in Vojvodina communities. From the total number of pulleys, 489 were taken into consideration because of incomplete answers.

During data processing collected by poll taking, descriptive statistic processing was applied which comprised methods of collecting, assortment and presentation of the data. All questions are processed by appliance of the adequate mathematic statistics method and computer software SPSS 11.15. Procedures of data processing and presentation were adjusted to the established criteria defined in the poll - survey.

On the base of conducted survey about attitudes of inhabitants considering condition and development of rural tourism in Vojvodina and data processing from the poll, we came to the following conclusions: the majority of polled think that natural, cultural historic and anthropogenic potentials were very good ( $89 \%$ of the total number of polled). According to citizens' opinion, touristic contents which attract the most tourists are cultural-historical contents and many of them also itemized the production of famous wines (78\% of the total number of the polled). Available prices of hotel services (accommodation, food, entertainment) are according to polled opinion acceptable (88\% give positive opinion), while roads condition and traffic infrastructure are not satisfactory. Most of the polled think that in cities the biggest disadvantage is lack of bicycle and pedestrian paths, and also badly developed traffic connection of city centres 
7 | SUSTAINABLE DEVELOPMENT OF RURAL AREAS - CASE STUDIES VOJVODINA SERBIA

with rural tourism centres, i.e. lack of organized transport to picnic places $(67 \%$ have such attitude). During conversations with polled, many of them emphasised the fact that streets in city centres are extremely narrow and that there was no possibility to be expanded for modern tourist buses necessity of high touristic classes and big dimensions. In the following sectionwe present one part of questions and answers from the survey:

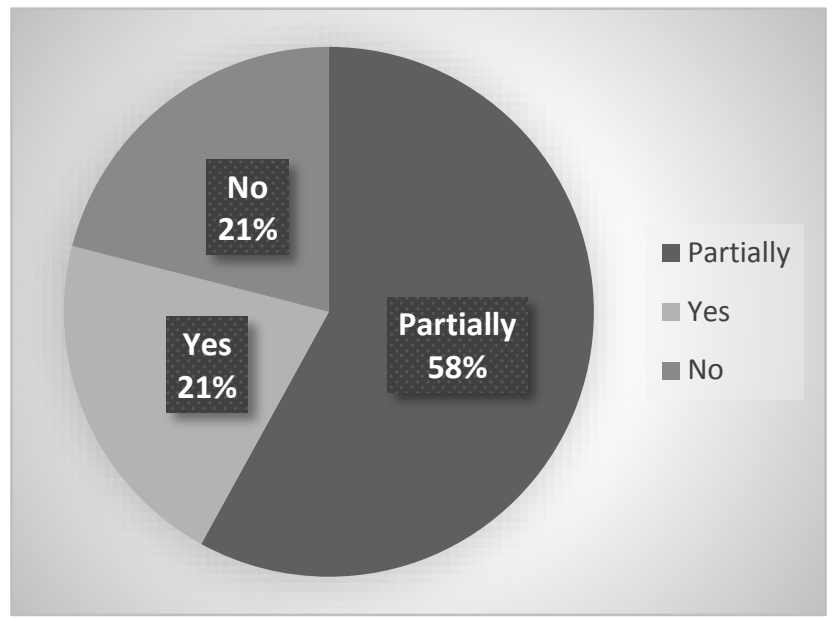

Picture 1. Have you been informed about possibilities of cross board and regional cooperation in tourism?

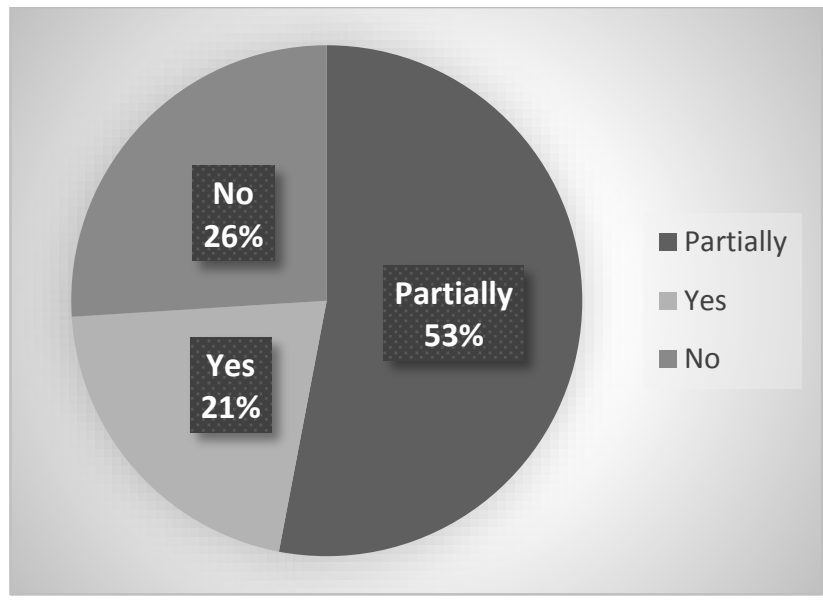

Picture 2. Have you been informed about possibilities of investments use from European Union funds? 
Dejana Forcan, Mladen Ivić, Dragan Đuranović, Veljko Vuković | 8

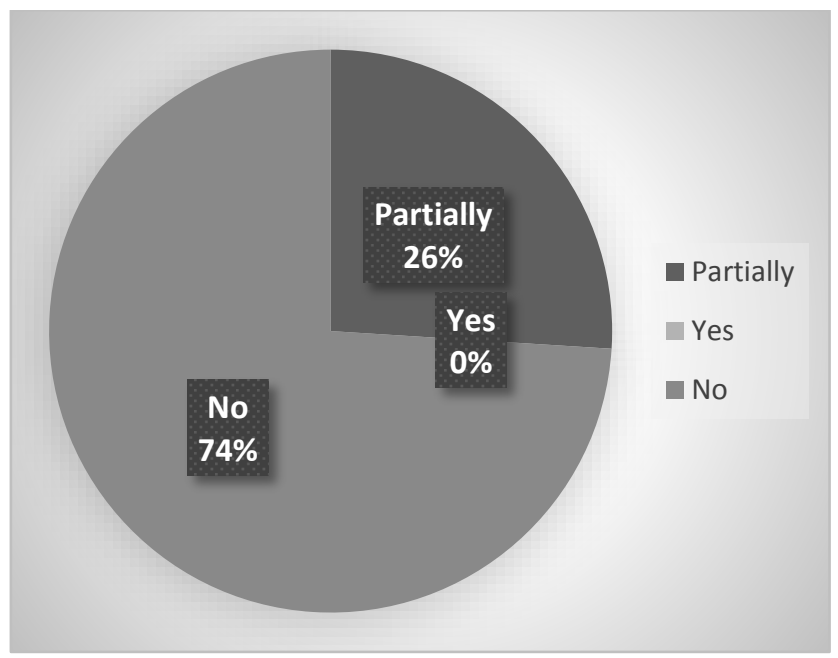

Picture 3. According to your opinion if European Funds for touristic projects are used enough?

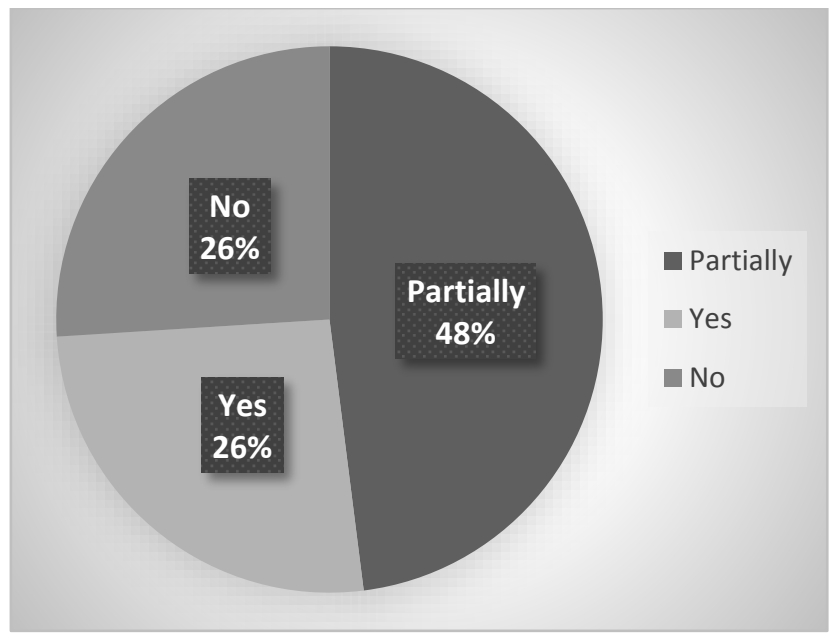

Picture 4. Have you been informed about procedures and rules which have to be followed for EU sources use? 
9 | SUSTAINABLE DEVELOPMENT OF RURAL AREAS - CASE STUDIES VOJVODINA SERBIA

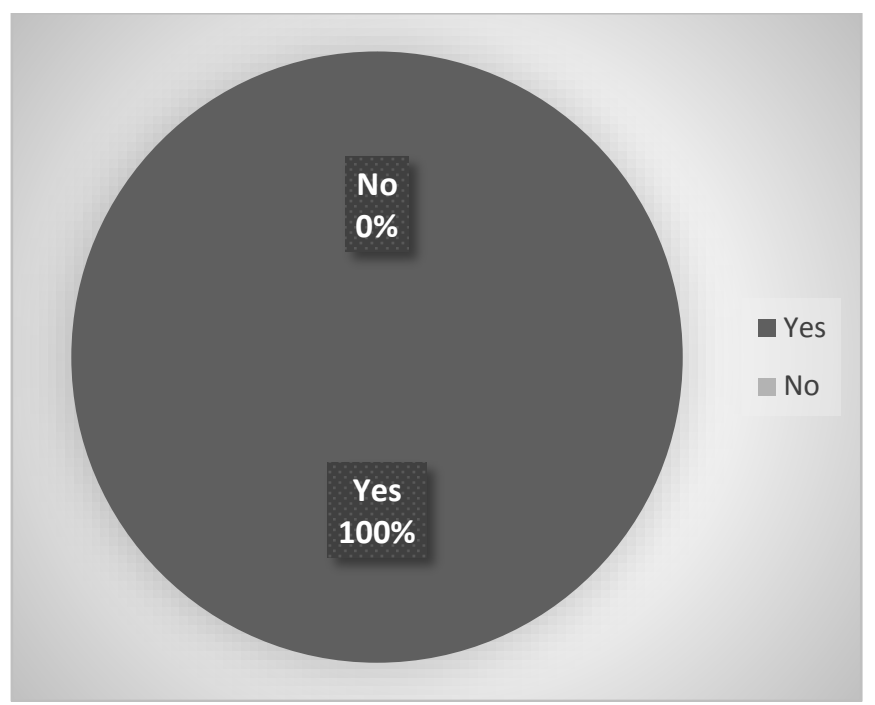

Picture 5. Pursuant to preparation and realization of projects complexity if education and tuition are necessary?

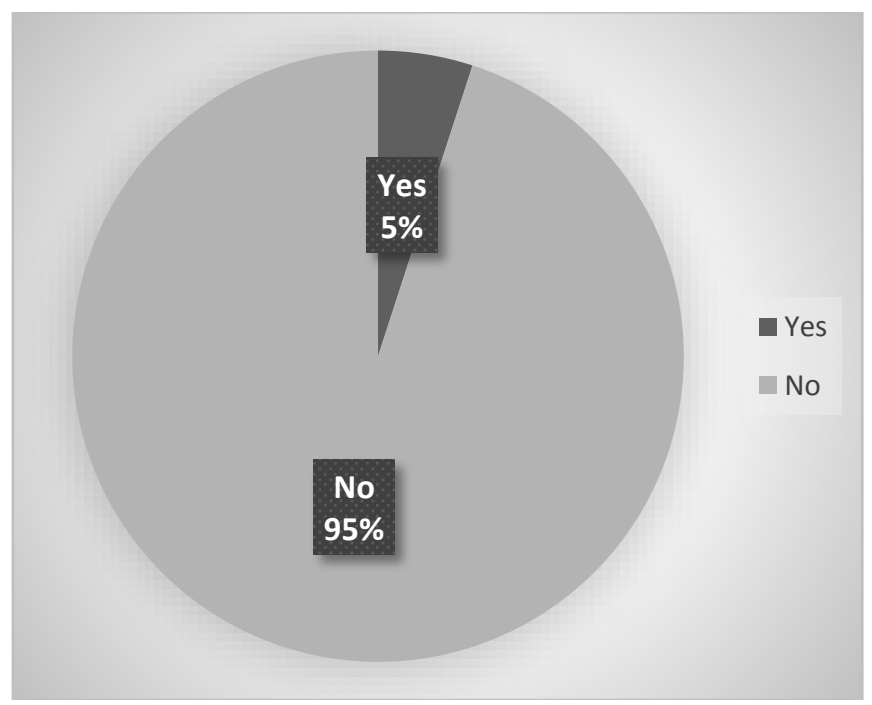

Picture 6. According to your opinion if there is enough number of tuitions about sources from EU funds use? 


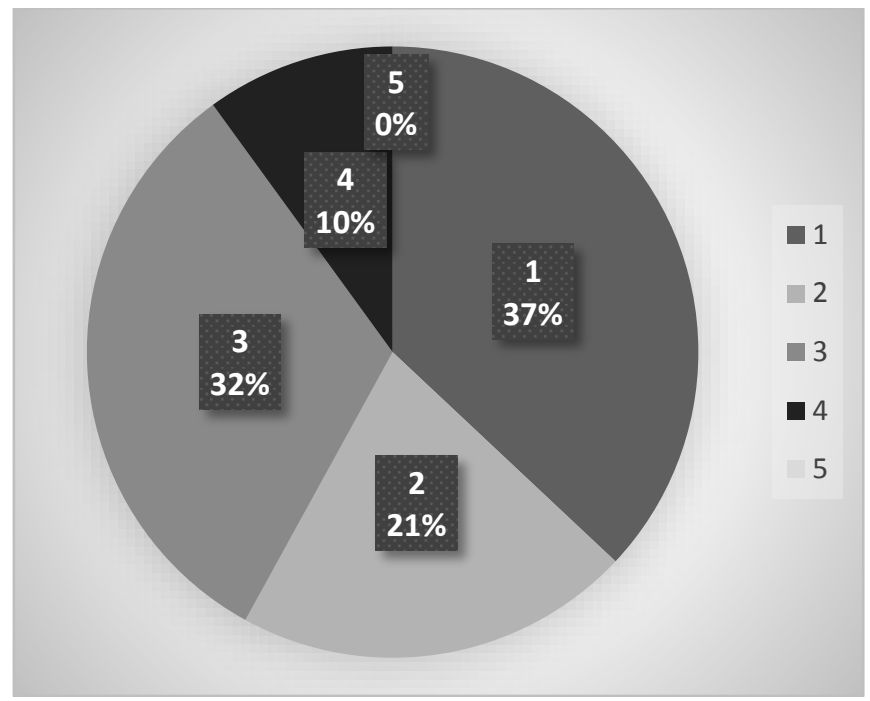

Picture 7. Estimate possibility of information providing about touristic projects financing from EuropeanUnion funds.

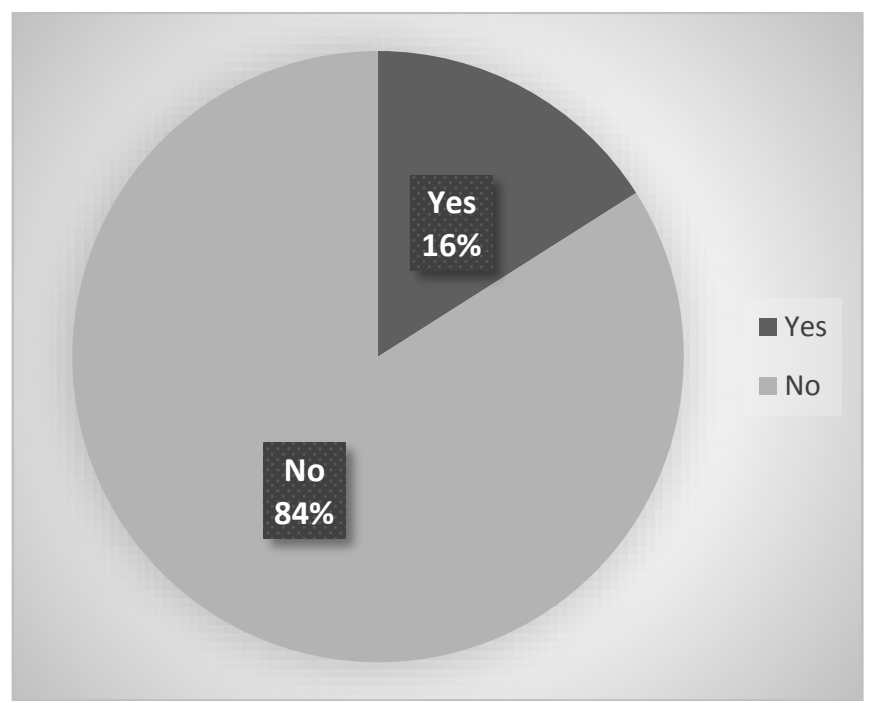

Picture 8. Have you participated in projects financed by EU?

The results of the primary research are proved the fact that touristic workers haven't been informed on appropriate way about possibilities and haven't yet recognized the importance of EU funds. Touristic subjects come hardly to the information about actual invitations for investment and co-investment of touristic projects in Vojvodina and Serbia. Although there were several SCHOOL OF BUSINESS, 2/2016, $1-13$ 

SERBIA

successful projects, relatively small number of projects is yearly submitted. Touristic subjects aren't familiar, nor informed on adequate way about complex procedures and rules which have to follow in order to use EU sources.

\section{CONLUDING REMARKS}

Villages and rural areas deterioration is identified as a global problem, so struggle against poverty, marginalization, depopulation and low living quality in rural areas in the most of countries became an act of political determination and high ranged development aim. Today EU policy of rural development is defined in Agenda 2000 and founded on multi-functionality of agriculture which comprises active rural tourism development (Dragin, Dragin, Plavša, Ivkov, \& Đurđev, 2007). .

In GDP structure of European Union service sector is dominant with percentage of $69,4 \%$ in relation to industrial of $28,4 \%$. Tourism would soon become the largest service industry in EU and would realise more than 13\% GDP (directly and indirectly), participating with $6 \%$ in the total employment and $30 \%$ in external trade exchange. Tourism presents the main source of working places today and in the future period also.

Rural tourism development depends on numerous different factors. Presuppositions for tourism development are stability and safety. Foreign investments, as well as tourists don't come if there is the smallest risk considering their safety (Mihić et al., 2012). Tourism development is in direct proportion with infrastructure development. Investment into road nets, railway, air and river transport is presupposition for tourism development. Also, without investment into capacities as in existent, so in new constructing, tourism development isn't possible. EU assists with no repayable sources and indirectly through funds of special assignment. By investment increasing into tourism, stability of a country is higher, mobility of goods and settlements, recruitment of cultural contacts, which reflects on the state image and tourists' attraction.

Surveys conducted within the project show that there is interest, but degree of information about the ways and possibilities for EU sources use for rural tourism development and tourism in general are very weak. It is undoubtedly one of the indicators which show that there is necessity for education in order to stimulate business initiatives and show how offered possibilities of EU funds could be used. 


\section{REFERENCE}

Dragin, A.S., Dragin, V., Plavša, J., Ivkov, A., \& Đurđev, B.S. (2007). Cruise ship tourism on the Danube in Vojvodina Province as a segment of global tourism. Geographica Pannonica, 11, 59-64.

Lopandić, D. (2007). The Reform of European Union, West Balkan and Serbia, Institute of economy sciences. (pp. 20-25). Belgrade.

Lopandić, D. (2004). EU and process of stabilization and compliance to states of JIE. Belgrade: Media centre.

Mihić, S., Muhi, B., Domazet, S., Mihajlović, M., \& Supić, D. (2013). Razvojni pravci turizma uz podršku fondova Evropske unije - šansa za privredni oporavak Vojvodine. Poslovna ekonomija, 7(2), 271-298. 9.

Mihić, S., Andrejević, A., \& Mihajlović, M. (2012a). Marketing odnosa - uloga i značaj u malim i srednjim preduzećima. Poslovna ekonomija, 6(1), 91103.

Mihić, S., Andrejević, A., \& Mihajlović, M. (2012b). Savremeni potrošači organska poljoprivreda u Srbiji - perspektive potrošnje organske hrane. Ekonomika, 58(2), 13-22.

Mihić, S., Golusin, M., \& Mihajlović, M. (2011). Policy and promotion of sustainable inland waterway transport in Europe-Danube River. Renewable and Sustainable Energy Reviews, 15(4), 1801-1809.

Mihić, S., Drobac, M., \& Mihajlović, M. (2010). Eko marketing u funkciji izvoza hrane. Ekonomika poljoprivrede, 57(1), 35-46.

Muhi, B. (2013). Rural tourism as a component of integral and sustainable rural development in Vojvodina. Collection of Matica srpska for social sciences, 142, 135-143.

Muhi, B. (2011). Simulative measures of European Union for tourism development in rural areas. Poslovna ekonomija, 5(1), 107-125.

Muhi, B. (2010). Rural tourism as factor of village revitalization in Vojvodina: Ehallenges and possible development directions. Economic of agriculture, Science Association of agrar economists of Balkan, 57(3), 475-487.

Plavsa, J. (2007). Recreational activities in rural tourism. (pp. 87-92). Department of geography.

Tomić, P., Romelić, J., Kicošev, S., Besermenji, S., Stojanović, V., Pavić, D., \& Korać, J. (2004). Zaštićena prirodna dobra i ekoturizam Vojvodine. 
13 | SUSTAINABLE DEVELOPMENT OF RURAL AREAS - CASE STUDIES VOJVODINA SERBIA

Prirodno-matematički fakultet - Departman za geografiju, turizam i hotelijerstvo.

Note: The research is financed by: Paper is a part of research within the project no. 114-451-3327/2013-04 dated June 15, 2013, according to resolution of classification 140 - Basic research position 498, Special research, economic classification 4246 - Environment protection services, science and geodetic services. This project is financed by Provincial secretariat for science and technological development.

Primljeno: 31.08 .2016$.

Odobreno: 06.09.2016. 